\title{
Determination of present-day stress tensor and neotectonic interval in the Spanish Central System and Madrid Basin, central Spain
}

\author{
G. De Vicente ${ }^{\text {a, }}$, J.L. Giner ${ }^{\text {a }}$, A. Muñoz-Martín ${ }^{\text {a }}$, J.M. González-Casado ${ }^{b}$, R. Lindo $^{c}$ \\ ${ }^{a}$ Departamento de Geodinámica, F. Ciencias Geológicas, Univ. Complutense, 28040, Madrid, Spain \\ ${ }^{b}$ Departamento de Geología y Geoquímica, F. Ciencias, Univ. Autónoma, 28049, Madrid, Spain \\ ${ }^{c}$ Institut de Physique du Globe, Strasbourg, France
}

Received 27 April 1995; accepted 20 June 1996

\begin{abstract}
A brittle deformation tectonic analysis was performed in central Spain (Spanish Central System and Madrid Basin) in order to decipher and understand the deformation processes that take place in a typical intracontinental zone. 1174 fault slickensides obtained in materials with ages between Late Cretaceous and Quaternary have been analyzed by means of fault population analysis methods to reconstruct paleostress tensors. Nine earthquake focal mechanisms have been determined, with magnitudes ranging between 3 and 4.1 .

With regard to regional structural features and sedimentary record data, the characteristics of present-day and neotectonic stress fields have been figured out, which determine the neotectonic period for this region.

Thus, we have established that the intraplate zone represented by central Spain has been subjected to a stress field from the Middle Miocene until the present-day with a largest horizontal shortening direction $\left(\mathrm{S}_{\mathrm{HMAX}}\right)$ located between N130E and N160E.

Finally, three paleostress maps with the main active structures are presented for: (a) Middle Miocene to Late Miocene, the period when the Spanish Central System was mainly formed, (b) Late Miocene to Quaternary, and (c) the present-day stress field, deduced from earthquake focal mechanisms.
\end{abstract}

Keywords: neotectonics; seismotectonic; fault; focal mechanism; active stresses; stress evolution; Central Spain

\section{Introduction}

The concept of 'present-day stress tensor' should be related directly with the term 'active tectonics', that is, the study of the earth deformation processes that are occurring at present, or could occur in the near future in a specific region (Wallace, 1986).

Depending on the author, the term 'neotectonics' could refer to the deformation processes that took

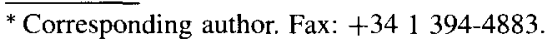

place from the end of the Tertiary (Neogene) or from the first half of the Quaternary to the present. However, we consider that it is more accurate to relate the neotectonic period with the time in which the present stress tensor has been active (Blenkisop, 1982). Thus, the neotectonic deformation phase begins at a different time in different places, depending on the tectonic and dynamic regime of the area in question (Mörner, 1990).

Therefore, we consider 'neotectonics' as the combined study of active processes and structures, and 
under the present-day stress tensor tectonic deformations produced by a paleostress tensor of similar characteristics to the current stress tensor.

On the one hand, in order to determine the present-day stress tensor, we could use: (a) geological methods (e.g. fault population analysis), (b) instrumental methods (e.g. 'in-situ' stress measurements) or (c) geophysical methods (e.g. analysis of earthquake focal mechanisms). On the other hand, only geological methods can be used when establishing paleostresses. In that case it has been demonstrated that fault population analysis methods give equivalent results to those of geophysical methods (Zoback, 1992).

With these considerations, it is necessary to measure several fault sets in materials of different ages in order to establish the characteristics of the current and neotectonic stress tensors, as well as the neotectonic period. A comparison of these results with those derived from the earthquake focal mechanism analysis is also required.

\section{I. Geological setting}

The Iberian Peninsula shows recent deformation structures in many places (mainly at its southern and eastern limits). The relative motion between the European and African plates has been convergent throughout the Neogene (Dewey et al., 1989). In the Iberian plate, during the N-S to NNW-SSE convergence and slip between these plates, stresses from the Pyrenean and Betic borders were transmitted into the Iberian Meseta (a part of the Iberian Massif outcropping in central Iberia). This stress field gave rise to a set of different intraplate chains and basins. Their structural characteristics are influenced by previous crustal structures and discontinuities, and by the thickness of the sedimentary cover.

The Iberian Range (Celtiberian Chain) (Fig. 1) separates two different domains: in the eastern part, outcrops of Mesozoic to Paleogene sedimentary cover dominate, while in the western zone, metamor- phic and plutonic Hercynian basement rocks cover almost the whole area.

Neogene and Quaternary tectonic activity produced a thick-skin style deformation, within the Iberian Meseta. Where crustal faults were reactivated with reverse movements, these faults generated a group of upward and downward moving basement blocks that produced Tertiary basins and intraplate chains. The orientation and distribution of these structures in Iberia follow a marked regular pattern. These structures are the following (Fig. 1), from north to south.

Cantabrian Mountains. This chain is the western continuation of the Pyrenees with topographic heights rising up to $2700 \mathrm{~m}$. These mountains have an important topographic relief given their vicinity to the sea. The boundary with the Duero Tertiary Basin consists of a reverse E-W trend fault that dips towards the north (Alonso et al., 1996).

Duero Basin. It is filled with Tertiary sediments, that thicken to more than $3000 \mathrm{~m}$ at its eastern part (Querol, 1989).

Spanish Central System. This range has a N60E trend, and altitudes close to $2500 \mathrm{~m}$. Its boundaries with the surrounding basins consist of two main faults with opposite dips, drawing a large crustal 'pop-up' (Vegas et al., 1990; De Vicente et al., 1994).

Madrid Basin. It is filled with fluvial and lacustrine Tertiary deposits. Next to the northern margin of this basin, the thickness of sediments reaches 3500 $\mathrm{m}$. Sediments are thrust by the basement (Megías et al., 1983).

Toledo Mountains. These mountains are lower than the Central System $(1500 \mathrm{~m})$, and have an E-W trend. They thrust northwards over Tertiary sediments of Madrid Basin.

Guadiana Depression. This structure does not have a generalized sedimentary cover. Its principal feature is the presence of important Middle Miocene and Pliocene volcanic activity (Ancoechea, 1982).

Sierra Morena Mountains. This mountainous range is south bounded by the Tertiary Guadalquivir

Fig. 1. Geographical and geological setting of the area of this study. SCS = Spanish Central System; $I R=$ Iberian Range; $A R=$ Altomira Range; $T M=$ Toledo Mountains; $G D=$ Guadiana Depression; $C M=$ Cantabrian Mountain; $l=$ Madrid Basin; $2=$ Duero Basin; $3=$ Ebro Basin; $4=$ Guadalquivir Basin. Below, position of microstructural analysis sites. Paleozoic, Mesozoic and Paleogene outcrops are showed in grey, Neogene in white. Line $A-B$ corresponds with the geological cross-section shown in Fig. 2. The coordinates correspond to UTM in $\mathrm{km}$. 

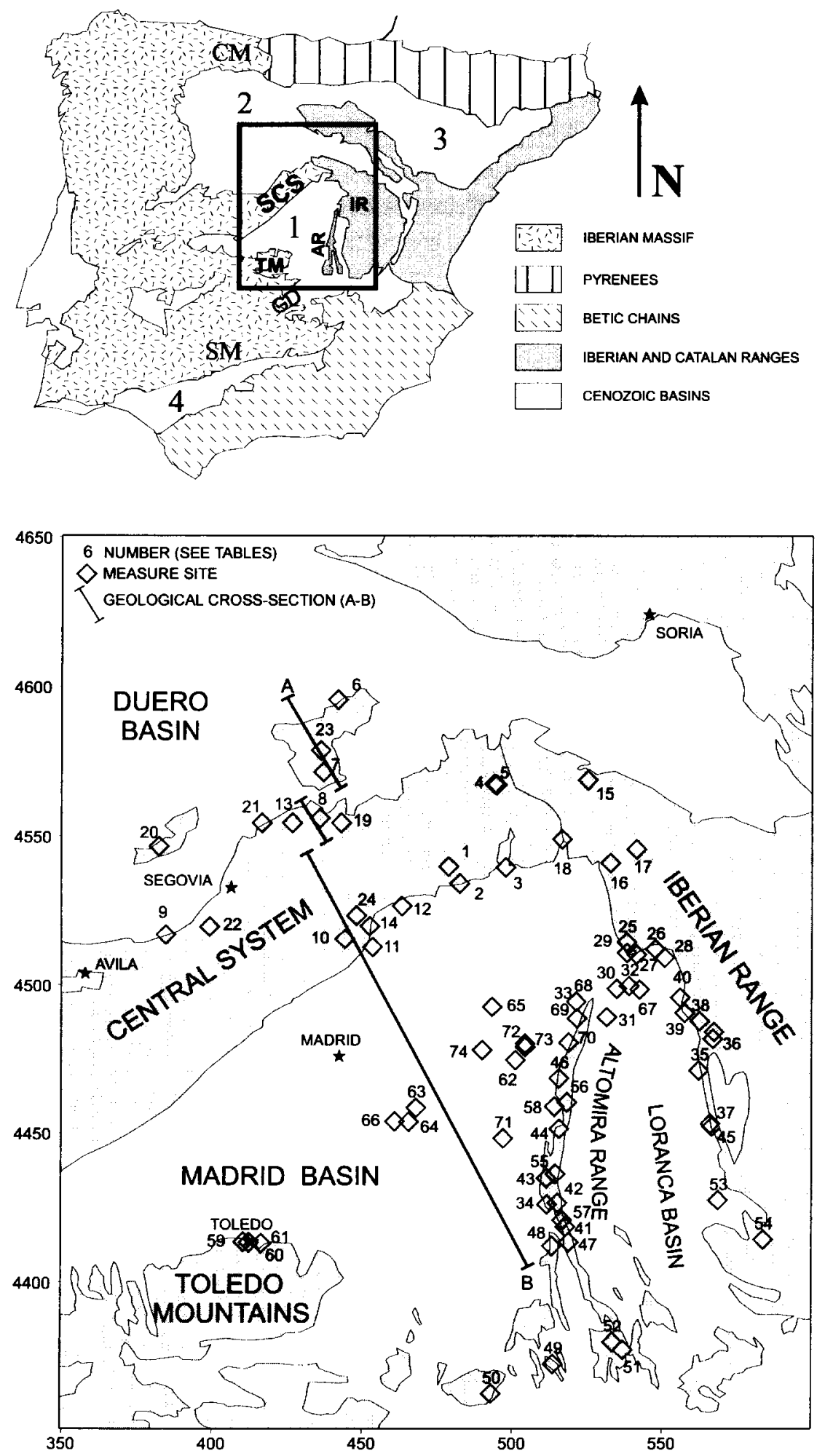
Basin, and the limit between these units has a N60E trend and consists of surficial normal faults, although they have been explained as a large crustal flexure (Van de Beek and Cloetingh, 1992).

All these basins and intraplate chains show important tectonic activity during the Neogene, and at present they exhibit a moderate seismic activity.

Our study focuses on the Central System, the Madrid Basin and its surroundings. Both features could be considered, in general, as good representatives of Neogene and recent deformation of the Iberian Hercynian basement that outcrops in this part of Spain.

The Madrid Basin has a well studied Neogene stratigraphy (Calvo et al., 1989, 1996), that allows us to apply paleostress analysis methods over a rather continuous sedimentary record. Geophysical information about this region, such as gravimetry and seismic reflexion profiles (Suriñach and Vegas, 1988; Querol, 1989; Babín et al., 1993; Pérez Agudo, 1995), is abundant, therefore the sub-surficial characteristics of the Madrid Basin can be determined. There is also accurate information of the date and rate of the Central System uplift, from fission-track studies (Sell et al., 1995).

Two research approaches have been employed in order to establish the present and neotectonic stress tensors. On the one hand, fault populations in Mesozoic and Paleogene materials have been measured at the basin margins, as well as in Neogene and Quaternary materials of the basin centre. On the other hand, a set of 9 focal mechanisms of earthquakes with magnitudes between 3 and 4.1 has been studied.

Thus, the objective of this study is the establishment of the present-day and neotectonics stress tensor characteristics, as well as the neotectonic period in an intraplate zone such as the Spanish Central System and the Madrid Basin.

\section{Paleostress analysis methods}

Three independent analysis procedures have been used to infer the current and neotectonics stress tensors.

(a) Fault population analyses (FPA) have been used to determine paleostress fields. These procedures allow us to establish a reduced stress tensor that activates the fault populations measured in the field. All methods are based on brittle deformation conditions, without volume change.

Most stress inversion methods are based on Bott's equation (Bott, 1959):

$\tan \theta=\frac{n}{l m}\left[m^{2}-\left(1-n^{2}\right) R^{\prime}\right]$

This equation relates the shape $\left(R^{\prime}=\left(\sigma_{z}-\right.\right.$ $\left.\left.\sigma_{x}\right) /\left(\sigma_{y}-\sigma_{x}\right)\right)$ and orientation of the stress tensor principal axes $\left(\sigma_{y}, \sigma_{x}\right.$ and $\left.\sigma_{z}\right)$ to the fault plane orientation $(l, m, n$ are the fault directional cosines) and to the slip line $(\theta$, the theoretical striation pitch on the fault plane).

The stress inversion method (SIM) proposed by Reches (1987) and Reches et al. (1992) has been used here because it assumes the Navier-Coulomb rupture principle as well as Bott's equation, so that cohesion, friction coefficient and other physical variables are taken into account.

(b) An analysis procedure, similar to the previous one, is performed in order to calculate the strain ellipsoid from a fault population. In both cases, parallelism between strain and stress principal axes is assumed. A direct method (De Vicente, 1988; Capote et al., 1991) based on the slip model (SM) (Reches, 1983) was developed, which relates the strain ellipsoid shape ( $K=e_{1} / e_{3}, e_{i}$ ellipsoid principal axes) with the fault orientation ( $D$, dip) and the striae defining the slip line $\left(B=\sin ^{2} D \cdot \cos ^{2} P\right.$, being $P$ the slip line's pitch and $D$, the fault dip) by means of the equation:

$$
K=\frac{\sin ^{2} D \cos ^{2} B}{1-\sin ^{2} D \cos ^{2} B}
$$

(c) The method of Rivera and Cisternas (1990) has been applied to determine the regional stress tensor from earthquake focal mechanisms. This procedure uses Bott's equation combined with the radiation pattern function for $P$ waves first arrivals. At the same time, it seeks the maximum of the likelihood function, which depends on the radiation function and on the probability of obtaining either a positive or a negative polarity. Since this is a trial-and-error procedure, it makes use of a set of stress tensors and focal mechanisms as starting conditions. Its results are similar and comparable to those of the classical FPA methods (e.g., Etchecopar, 1984; Angelier, 1990). It is remarkable that this method has been used in the determination of the current stress field 
of France (Delouis et al., 1993) with satisfactory results.

Once the stress tensor for each site of measurement is obtained, the possible deformation age limits are assigned depending on the age of the materials where fault striations were measured, their structural situation, and their position in the sedimentary record of the Madrid Basin.

\section{Structure of the Madrid Basin margins}

The Tertiary evolution of the Madrid Basin and its margins is essential to evaluate and correlate the paleostress data presented further on. Hence, we will start with an accurate description of the structure of the Madrid Basin margins.

The Madrid Basin has a triangular geometry. The southern boundary is formed by the Toledo Mountains, while the southwestern prolongation of this limit is less well-defined and onlaps with the Guadiana Depression; the NW boundary is the Central System, and consists of a sharp north-dipping thrust, while the eastern limit with the Iberian Range is rather less defined. Moreover, in the eastern zone, the N-S-trending Altomira Range (Fig. 1), separates the Madrid Basin from the Loranca Basin.

\subsection{Spanish Central System}

This is a straight mountain range, elongated along a principal NE-SW trend. This direction corresponds to several reverse faults that uplifted the basement, causing a double vergence chain with a thick skin tectonic style (Fig. 2). The basement appears clearly involved in this deformation, and there are no observable detachment levels in the cover. The shortening related to the NE-SW- and E-W-thrusting is laterally resolved by strike-slip faults (transfer faults), with N140E (dextral movement) and N10E (sinistral movement) trends (De Vicente and GonzálezCasado, 1991) (Fig. 3B). The largest horizontal shortening related with the fault displacement has a N155E trend (Capote et al., 1990). The restored section shows a crustal 'pop-up' structure for the Central System, with an associated shortening of $22 \%$ (Fig. 2). In more detail, three minor pop-up structures appear at the southern part, which draw a series of folds with different widths; open anticlines separated by tight synclines. Their wave longitude fluctuates between 5 and $10 \mathrm{~km}$. The northernmost zone has a different structure, with a series of imbricate thrusts from which a $4 \mathrm{~km}$ deep NW-verging detachment level can be inferred. This style difference could be a response to different materials in the basement, granites to the south and metamorphic foliated rocks to the north.

The boundaries of the Central System are formed by two reverse faults (the north, NBF, and the south, SBF, border faults). However, it can be observed that, while the southern border (SBF) coincides with the topographic limit (STL), the northern border is displaced towards the south with respect to the NBF. This points to a different spatial and temporal behaviour of the northern and the southern border faults. This fact is also obvious in the Upper Miocene facies distribution: the lacustrine sedimentary deposits (UMLDL) appear next to the NBF, while they are located towards the centre of the Madrid Basin at the south (Figs. 2 and 3B).

\subsection{Toledo Mountains}

These form the southern border of the Madrid Basin. In its northern limit the main structures of this mountain range are several E-W thrusts, dipping to the north. The northernmost thrust produces the overlap of basement rocks over Cenozoic sediments belonging to the Madrid Basin. The shortening direction associated with reverse fault movements shows a N-S trend, similar to that of the western end of the Central System, a region with several features similar to this. Nevertheless, due to the minor topographic expression of this mountainous alignment, it is reasonable to infer that: (a) the alpine deformation intensity was lower than in the Central System; and (b) they were structured first. This latter hypothesis cannot be rejected, given the current knowledge of the sedimentary basin-fill of the Madrid Basin in this area (Calvo et al., 1989).

In any case, Toledo Mountains do not close the Madrid Basin, since they finish to the east in a set of N140E striking dextral faults, partly sealed by Pliocene and Neogene sediments. These sediments connect the southern part of the Madrid Basin with the Guadiana Depression (Figs. 1 and 3B). 


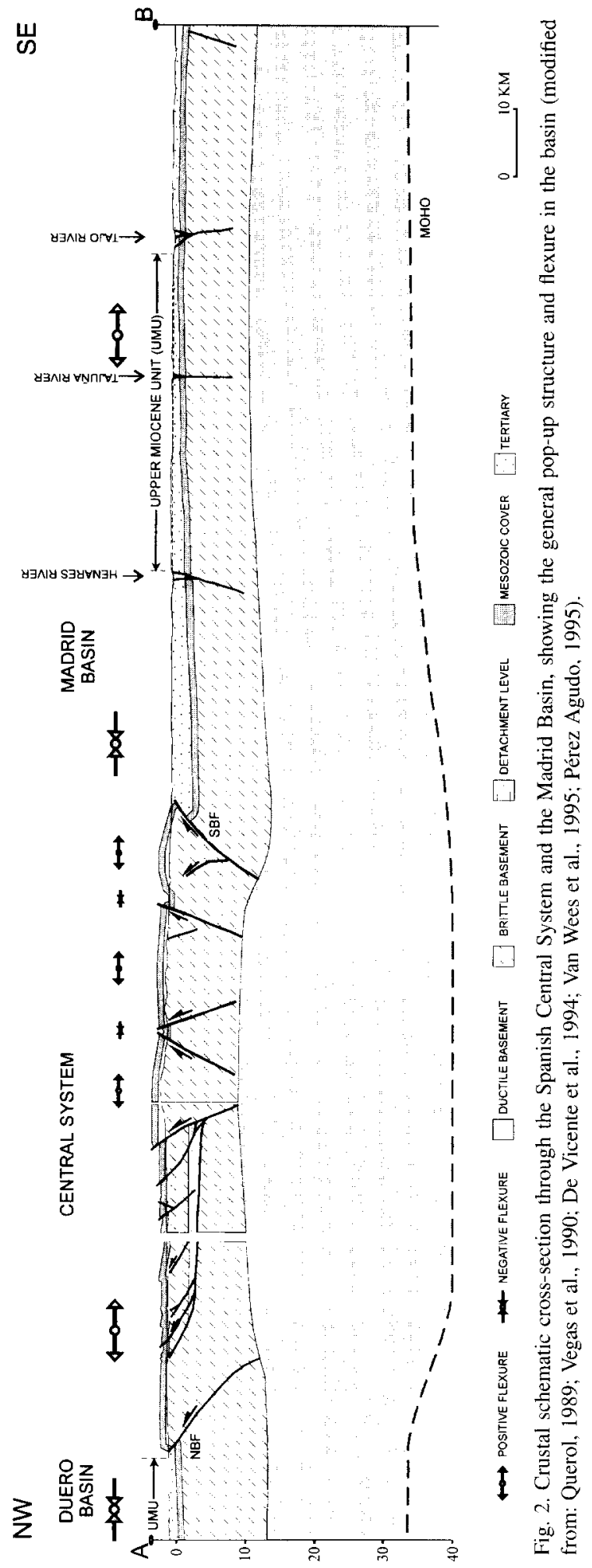




\subsection{Iberian Range (Celtiberian Chain)}

The Iberian Range is the only boundary of the Madrid Basin with a several thousand metres thick Mesozoic cover, that is locally detached. This is a polyphase chain, structured at least in two episodes: one related to the Oligocene aged Pyrenean stress field, (Simón-Gómez, 1986), and the other with the NW-SE-shortening direction developed during the Neogene, and probably related to the Betic paleostress field (De De Vicente, 1988). This latter deformation is more intense in the westernmost sector and it is related to the Central System evolution. In fact, this sector of the Iberian Mountain Range constitutes the main lateral limit of the Central System N60E thrusts, given rise to a transpressive zone, with numerous N140E-trending dextral strike-slip faults. This deformation yielded lower topographical heights than the Central System.

The microstructural analysis records a last strong extensional process perpendicular to the chain. These stresses reactivated previous N140E faults as normal ones (Simón-Gómez, 1986). The important topographic gradients that appear throughout the chain are due to the rapid erosional processes of the fluvial network.

The eastern part of Iberian Peninsula has been subjected to stretching due to rifting process, which began in the Middle Miocene (Simón-Gómez, 1986; García-Cuevas et al., 1995). This type of deformation is not recorded in the Madrid Basin, at least until the Late Miocene, although it is more likely that it has a Pliocene age. At the end of the Pliocene, a very characteristic erosional surface was developed (the 'Paramo' surface), that is deformed nowadays, forming a large flexure with an axis parallel to the Iberian Range western sector (NW-SE). This area shows the major erosional processes in the fluvial network. In the Madrid Basin, rivers run southwest, showing a recent tilt in this direction that corresponds to the Iberian flexure's southwest flank.

This Pliocene uplifting has been related with the late evolution of the Valencia Trough opening process (Janssen et al., 1993), although the perpendicular disposition between the described structure and the rift (NE-SW) could suggest that the process was not uniaxial.

\subsection{Altomira Range}

This range is a straight alpine N-S-trending foldand-thrust-belt that separates the Madrid and Loranca Tertiary basins. This structure was active from the Late Oligocene to the Early Miocene (DíazMolina et al., 1989; Díaz-Molina and Tortosa, 1996). The study of the sedimentary record and related structures indicates an important decrease in the tectonic activity during the Middle to Late Miocene: slightly deformed sedimentary deposits of this age onlap the reliefs of the Altomira Range in some places (Rodríguez-Aranda, 1995), suggesting a tectonically passive phase during this period.

The Mesozoic and Cenozoic cover is detached at Triassic Keuper gypsum beds (levels of larger ductility contrast), as can be observed in seismic reflection profiles (Querol, 1989). The western limit of these facies seems to control the formation of these detachments (Van Wees et al., 1995). However, the presence of important basement faults also influences the localization of the thrust and fault propagation folds (Perucha et al., 1995). These basement faults also control the lateral termination of the thrust, defining different vergence zones.

The maximum horizontal shortening direction associated with the formation of this mountain range is N100E. The genesis of these mountains has been explained as the result of a superposition of two regional stress directions, the Pyrenean and the Betic paleostress fields (Muñoz-Martín et al., 1994), which could have produced a westward escape of the Altomira Range, in a general N-S compressive stress field.

\section{Establishment of Neogene and Quaternary stress fields}

In this study 74 measurement sites have been analyzed, with a total of 1174 studied faults (Table 1), and an average of 16 faults per site. This is a reasonable number for recent materials. A largest SE-trending horizontal shortening $\left(\mathrm{S}_{\mathrm{HMAX}}\right)$ appears as the main solution at all sites. With regard to the age of the materials and to their structural position, the sites can be divided in two broad groups.

The first group consists of the data measured in rocks older than Late Miocene at the Madrid Basin 

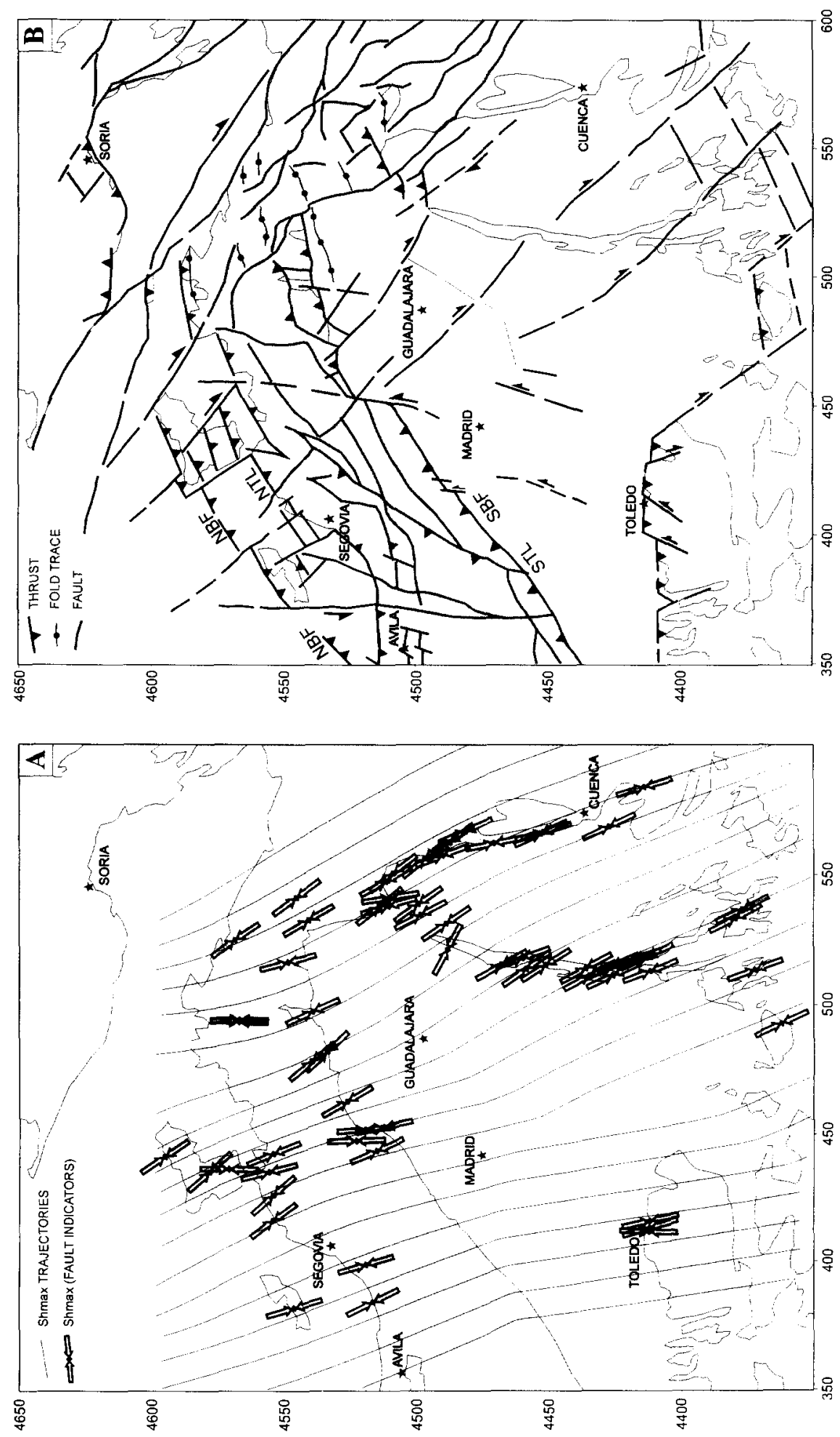

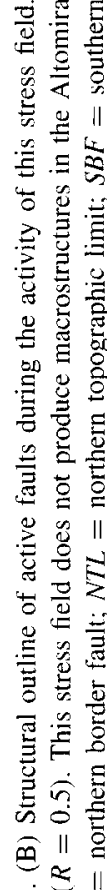

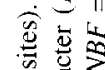

b ⿹ㅛㅇ

害

要

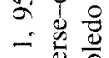

름

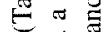

긍 苛

㱐

氙 可

高 $\times$

可话导

표에

话 5

密行

을 영응

농

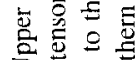

可

青

矛苟的

安品焉

mi

幽密 
margins (Table 1,1 to 61 sites). There are some sites in this group that are measured in main faults that, although it is not possible to exclude that these fault populations are not too large, they give very relevant information. Even though it is not possible to exclude a younger fault movement age (Late Miocene or Quaternary), we consider that the main tectonic activity event in the basin margins (Middle Miocene, see next section), must be reflected in the main faults located along these borders.

The second group is formed by fault populations measured in the sedimentary basin-fill of the Tajo Basin, in Late Miocene and younger rocks (Table 2, 62 to 74 sites. Station 69 was obtained in Middle Miocene sediments, but due to their structural position it has been considered as belonging to this group). Taking the Upper Miocene and Quaternary outcrop spacial distribution into account, it is difficult to obtain data near the Madrid Basin margins. Anyhow, this group of solutions records the most recent stress field.

(1) Middle to Upper Miocene paleostress field. Faults were measured mainly not only in Upper Cretaceous materials, but also on Paleogene formations (5 sites) and Paleozoic rocks that overlap some Upper Cretaceous and Paleogene rocks (zone of Toledo, 2 sites), at the Madrid basin margins.

In general, all the sites where faults have been analyzed show a N155E largest horizontal shortening, but the easternmost sites (Altomira and Iberian ranges) show other fault population results. This indicates E-W and NNE-SSW largest horizontal shortening directions. The E-W trend is related to the emplacement of the Altomira Range during the Late Oligocene to the Early Miocene (DíazMolina et al., 1989; Díaz-Molina and Tortosa, 1996; Rodríguez-Aranda, 1995). Compression patterns appear in the northeastern quadrant of the Iberian Range, that could be related to the paleostress field generated by the Paleogene Pyrenean formation (Muñoz-Martín et al., 1994). Nevertheless, sites considered in the Central System have only one solution, with a largest horizontal shortening towards N155E.

If we analyze the stress tensor characteristics related to each fault-slip station, it is possible to find all types of solutions: compressive, extensive and strike-slip stress regimes. However, $\mathrm{S}_{\text {HMAX }}$ shows always a SE trend (except in the Toledo Mountains, with a N-S trend). The most comprehensive solution, for this group of sites, suggests a strike-slip stress tensor ( $R=0.3$ ) (Fig. 5).

Fig. $3 \mathrm{~A}$ shows $\mathrm{S}_{\text {HMAX }}$ trends for each station. Results obtained with the 'slip model' (Reches, 1983) and stress inversion method (Reches et al., 1992) are similar. Construction of a $\mathrm{S}_{\mathrm{HMAX}}$ trajectories map has been carried out by means of an interpolation program, the LISSAGE program (Lee and Angelier, 1994). A regular $S_{\text {HMAX }}$ trajectories map is obtained, with a clockwise rotation towards the west due to Toledo Mountains paleostress data. We consider this paleostress field as the cause of the Central System and western branch of the Iberian Range deformation. Taking this paleostress field and the sedimentary basin-fill characteristics in the Madrid Basin into account, Middle Miocene active structures are shown in Fig. 3B.

(2) Upper Miocene to Quaternary paleostress field. 13 fault-slip sites in the central part of the Madrid Basin have extensional and strike-slip solutions (sites 63, 67, 68, 69 and 74) (Fig. 5, Table 2). Fig. 4A shows the $S_{\text {HMAX }}$ trajectories map. There is a group of NE-SW-trending normal faults in this zone, with a $S E$-trending $S_{\text {HMIN }}$. Field relationships between this normal fault set and the previously described one, suggest a synchronous movement. Therefore, it is impossible to define two different stress fields. Paleostress data sites showing a SE extension have not been considered in this analysis, although they are as abundant as the SE-NW compression sites.

The amount of tectonic deformation related to the uplifting of the Central System is smaller during this period than during the Middle Miocene, but this has to be confirmed by other techniques. Sedimentary and structural data show that the Toledo Mountains have not been very active during this period. Fig. 5B shows active structures during the Late Miocene and the Quaternary.

\section{Relationship between tectonics and sedimentary infilling of the Madrid Basin}

The thickness of the Tertiary sediments in the Madrid Basin ranges between 2000 and $3500 \mathrm{~m}$. The Neogene sedimentary sequence overlies dis- 
Table 1

Strain ellipsoids and stress tensors determined by the 'slip model' (Reches, 1983) and by the stress inversion method (Reches, 1987; Reches et al., 1992)

\begin{tabular}{|c|c|c|c|c|c|c|c|c|c|c|c|c|}
\hline \multirow[t]{2}{*}{ Stat. } & \multirow[t]{2}{*}{ N.F. } & \multicolumn{3}{|c|}{ Slip model } & \multicolumn{7}{|c|}{ Stress inversion } & \multirow[t]{2}{*}{ Age } \\
\hline & & Dey & S.D. & $K^{\prime}$ & $\sigma_{1}$ & $\sigma_{2}$ & $\sigma_{3}$ & ERR & $R$ & E.F. & $\mu$ & \\
\hline 1 & 31 & 146 & 7 & -1.145 & $00 / 320$ & $32 / 230$ & $57 / 050$ & 10 & 0.09 & 24 & 0.6 & Upper Cretaceous \\
\hline 2 & 20 & 145 & 8 & -1.384 & $03 / 316$ & $76 / 060$ & $13 / 225$ & 13 & 0.16 & 13 & 1.0 & Upper Cretaceous \\
\hline 3 & 24 & 167 & 11 & 0.093 & $78 / 347$ & $11 / 155$ & $02 / 245$ & 27 & 0.11 & 18 & 1.0 & Upper Cretaceous \\
\hline 4 & 23 & 1 & 9 & -13.55 & $04 / 002$ & $84 / 217$ & $03 / 092$ & 5 & 0.47 & 17 & 1.1 & Upper Cretaceous \\
\hline 5 & 27 & 178 & 9 & -1.207 & $00 / 000$ & $70 / 092$ & $19 / 270$ & 8 & 0.10 & 18 & 0.4 & Upper Cretaceous \\
\hline 6 & 12 & 153 & 9 & 1.804 & $60 / 346$ & $27 / 145$ & $8 / 240$ & 9 & 0.61 & 8 & 0.9 & Upper Cretaceous \\
\hline 7 & 10 & 174 & 11 & -1.292 & $05 / 357$ & $34 / 264$ & $54 / 095$ & 10 & 0.05 & 9 & 0.5 & Upper Cretaceous \\
\hline 8 & 7 & 169 & 10 & -1.008 & $03 / 165$ & $13 / 075$ & $76 / 269$ & 6 & 0.31 & 7 & 0.8 & Upper Cretaceous \\
\hline 9 & 10 & 153 & 6 & 24.84 & $35 / 333$ & $54 / 144$ & $04 / 240$ & 1 & 0.30 & 8 & 0.7 & Upper Cretaceous \\
\hline 10 & 12 & 153 & 11 & -1.894 & $31 / 155$ & $58 / 337$ & $00 / 246$ & 13 & 0.37 & 12 & 0.4 & Paleogene \\
\hline 11 & 9 & 166 & 9 & 16.12 & $79 / 298$ & $06 / 173$ & $08 / 082$ & 2 & 0.28 & 5 & 0.2 & Upper Cretaceous \\
\hline 12 & 15 & 145 & 7 & -1.014 & $04 / 149$ & $02 / 240$ & $84 / 000$ & 22 & 0.58 & 14 & 1.0 & Upper Cretaceous \\
\hline 13 & 8 & 158 & 9 & -1.022 & $14 / 137$ & $30 / 038$ & $55 / 249$ & 6 & 0.18 & 7 & 0.5 & Upper Cretaceous \\
\hline 14 & 19 & 168 & 9 & 3.773 & $01 / 335$ & $87 / 114$ & $02 / 265$ & 9 & 0.37 & 12 & 0.3 & Upper Cretaceous \\
\hline 15 & 14 & 152 & 9 & -1.276 & $04 / 324$ & $51 / 061$ & $37 / 230$ & 9 & 0.05 & 9 & 0.5 & Jurassic \\
\hline 16 & 25 & 154 & 7 & 1.925 & $64 / 134$ & $24 / 334$ & $07 / 240$ & 4 & 0.56 & 18 & 0.6 & Jurassic \\
\hline 17 & 8 & 146 & 6 & 5.817 & $12 / 323$ & $77 / 169$ & $03 / 054$ & 2 & 0.39 & 7 & 0.9 & Jurassic \\
\hline 18 & 10 & 152 & 7 & 0.487 & $07 / 334$ & $77 / 217$ & $09 / 075$ & 12 & 0.52 & 8 & 0.4 & Upper Cretaceous \\
\hline 19 & 19 & 163 & 5 & -1.035 & $02 / 157$ & $07 / 066$ & $82 / 268$ & 8 & 0.3 & 19 & 0.6 & Upper Cretaceous \\
\hline 20 & 21 & 162 & 9 & -1.148 & $10 / 163$ & $70 / 285$ & $16 / 070$ & 16 & 0.21 & 18 & 0.6 & Upper Cretaceous \\
\hline 21 & 16 & 151 & 8 & -1.023 & $09 / 142$ & $21 / 048$ & $66 / 255$ & 9 & 0.15 & 16 & 0.9 & Paleogene \\
\hline 22 & 19 & 160 & 9 & 18.79 & $88 / 185$ & $01 / 343$ & $00 / 073$ & 1 & 0.80 & 16 & 0.8 & Upper Cretaceous \\
\hline 23 & 10 & 155 & 17 & 0.323 & $83 / 305$ & $06 / 137$ & $01 / 047$ & 7 & 0.34 & 10 & 0.6 & Paleozoic \\
\hline 24 & 12 & 169 & 12 & 36.75 & $83 / 009$ & $05 / 178$ & $02 / 168$ & 6 & 0.86 & 11 & 0.8 & Paleozoic \\
\hline 25 & 10 & 138 & 5 & 1.01 & $15 / 141$ & $74 / 328$ & $01 / 232$ & 9 & 0.25 & 8 & 0.3 & Upper Cretaceous \\
\hline 26 & 9 & 152 & 7 & -1.418 & $00 / 331$ & $63 / 240$ & $26 / 061$ & 5 & 0.18 & 6 & 0.5 & Paleogene \\
\hline 27 & 15 & 171 & 8 & 1.22 & $12 / 344$ & $63 / 228$ & $22 / 080$ & 8 & 0.31 & 11 & 0.3 & Upper Cretaceous \\
\hline 28 & 20 & 142 & 8 & -1.705 & $05 / 322$ & $26 / 229$ & $62 / 062$ & 5 & 0.03 & 12 & 0.7 & Upper Cretaceous \\
\hline 29 & 42 & 171 & 7 & -1.314 & $17 / 171$ & $65 / 303$ & $17 / 075$ & 15 & 0.20 & 39 & 0.4 & Upper Cretaceous \\
\hline 30 & 10 & 150 & 4 & 0.475 & $13 / 332$ & $76 / 152$ & $00 / 242$ & 17 & 0.58 & 8 & 0.5 & Upper Cretaceous \\
\hline 31 & 10 & 145 & 3 & -1.054 & $05 / 145$ & $33 / 052$ & $56 / 244$ & 10 & 0.13 & 7 & 1.1 & Paleogene \\
\hline 32 & 8 & 152 & 7 & 3.01 & $28 / 324$ & $60 / 164$ & $08 / 058$ & 5 & 0.43 & 6 & 0.4 & Lower Miocene \\
\hline 33 & 8 & 145 & 10 & -1.445 & $04 / 128$ & $58 / 020$ & $31 / 220$ & 15 & 0.31 & 5 & 0.2 & Middle Miocene \\
\hline 34 & 10 & 147 & 6 & 0.92 & $17 / 335$ & $68 / 118$ & $11 / 241$ & 8 & 0.30 & 10 & 0.4 & Upper Cretaceous \\
\hline 35 & 18 & 166 & 5 & 0.241 & $08 / 169$ & $71 / 285$ & $16 / 077$ & 9 & 0.19 & 12 & 0.4 & Upper Cretaceous \\
\hline 36 & 14 & 157 & 7 & 0.205 & $00 / 336$ & $85 / 078$ & $04 / 246$ & 23 & 0.75 & 11 & 0.3 & Upper Cretaceous \\
\hline 37 & 10 & 158 & 4 & 0.329 & $30 / 343$ & $56 / 134$ & $13 / 245$ & 2 & 0.35 & 8 & 0.5 & Upper Cretaceous \\
\hline 38 & 23 & 143 & 9 & 0.336 & $86 / 347$ & $03 / 142$ & $01 / 232$ & 11 & 0.34 & 18 & 0.8 & Upper Cretaceous \\
\hline 39 & 16 & 166 & 7 & 3.69 & $15 / 159$ & $65 / 033$ & $19 / 254$ & 9 & 0.36 & 16 & 0.4 & Upper Cretaceous \\
\hline 40 & 10 & 149 & 5 & -1.32 & $19 / 140$ & $61 / 271$ & $20 / 043$ & 8 & 0.17 & 10 & 0.6 & Upper Cretaceous \\
\hline 41 & 17 & 165 & 9 & 1.27 & $08 / 161$ & $69 / 272$ & $19 / 068$ & 7 & 0.31 & 12 & 0.4 & Upper Cretaceous \\
\hline 42 & 20 & 152 & 6 & 0.673 & $00 / 335$ & $89 / 130$ & $00 / 245$ & 13 & 0.38 & 18 & 0.4 & Upper Cretaceous \\
\hline 43 & 13 & 151 & 4 & 1.24 & $08 / 332$ & $81 / 134$ & $02 / 242$ & 11 & 0.41 & 12 & 0.4 & Upper Cretaceous \\
\hline 44 & 9 & 152 & 4 & 1.49 & $85 / 357$ & $03 / 147$ & $02 / 237$ & 4 & 0.59 & 9 & 0.6 & Upper Cretaceous \\
\hline 45 & 23 & 154 & 5 & 0.525 & $74 / 146$ & $15 / 335$ & $02 / 244$ & 11 & 0.43 & 18 & 0.8 & Upper Cretaceous \\
\hline 46 & 6 & 154 & 4 & 3.998 & $17 / 326$ & $72 / 356$ & $02 / 057$ & 6 & 0.74 & 12 & 0.8 & Upper Cretaceous \\
\hline 47 & 6 & 153 & 2 & 1.19 & $59 / 164$ & $30 / 335$ & $03 / 068$ & 15 & 0.34 & 6 & 0.6 & Upper Cretaceous \\
\hline 48 & 11 & 158 & 5 & 0.472 & $05 / 154$ & $72 / 046$ & $16 / 245$ & 5 & 0.24 & 11 & 0.4 & Upper Cretaceous \\
\hline 49 & 50 & 158 & 8 & -1.234 & $08 / 159$ & $70 / 275$ & $17 / 066$ & 7 & 0.13 & 33 & 0.5 & Upper Cretaceous \\
\hline 50 & 14 & 159 & 5 & 10.81 & $86 / 033$ & $01 / 155$ & $02 / 245$ & 19 & 0.82 & 14 & 0.6 & Upper Cretaceous \\
\hline
\end{tabular}


Table 1 (continued)

\begin{tabular}{|c|c|c|c|c|c|c|c|c|c|c|c|c|}
\hline \multirow[t]{2}{*}{ Stat. } & \multirow[t]{2}{*}{ N.F. } & \multicolumn{3}{|c|}{ Slip model } & \multicolumn{7}{|c|}{ Stress inversion } & \multirow[t]{2}{*}{ Age } \\
\hline & & Dey & S.D. & $K^{\prime}$ & $\sigma_{1}$ & $\sigma_{2}$ & $\sigma_{3}$ & ERR & $R$ & E.F. & $\mu$ & \\
\hline 51 & 15 & 156 & 5 & 0.355 & $76 / 144$ & $13 / 334$ & $02 / 243$ & 5 & 0.56 & 11 & 0.6 & Upper Cretaceous \\
\hline 52 & 9 & 154 & 6 & 0.251 & $78 / 143$ & $10 / 332$ & $01 / 241$ & 4 & 0.68 & 7 & 0.8 & Upper Cretaceous \\
\hline 53 & 31 & 154 & 6 & -1.36 & $00 / 334$ & $68 / 243$ & $21 / 064$ & 12 & 0.10 & 24 & 0.7 & Upper Cretaceous \\
\hline 54 & 17 & 159 & 5 & 0.535 & $12 / 343$ & $77 / 162$ & $00 / 253$ & 17 & 0.45 & 15 & 0.7 & Upper Cretaceous \\
\hline 55 & 17 & 149 & 6 & 0.8 & $15 / 151$ & $71 / 008$ & $10 / 244$ & 21 & 0.30 & 15 & 0.6 & Upper Cretaceous \\
\hline 56 & 13 & 162 & 4 & 1.61 & $02 / 160$ & $83 / 273$ & $06 / 070$ & 5 & 0.48 & 10 & 0.6 & Upper Cretaceous \\
\hline 57 & 8 & 161 & 3 & 4.67 & $02 / 164$ & $79 / 061$ & $09 / 255$ & 4 & 0.17 & 8 & 0.3 & Upper Cretaceous \\
\hline 58 & 24 & 151 & 5 & 4.7 & $04 / 144$ & $82 / 015$ & $05 / 234$ & 6 & 0.45 & 22 & 0.8 & Paleogene \\
\hline 59 & 19 & 2 & 11 & 0.632 & $06 / 347$ & $14 / 079$ & $73 / 232$ & 18 & 0.55 & 16 & 0.2 & Upper Cretaceous \\
\hline 60 & 16 & 1 & 9 & 0.732 & $64 / 322$ & $20 / 182$ & $15 / 086$ & 15 & 0.75 & 10 & 0.4 & Paleozoic \\
\hline 61 & 11 & 35 & 8 & 0.688 & $63 / 195$ & $22 / 343$ & $12 / 078$ & 10 & 0.12 & 6 & 1.3 & Paleozoic \\
\hline
\end{tabular}

Stat.: number of measure sites. N.F.: number of faults. Dey: largest horizontal shortening direction. $K^{\prime}$ : ey/ez. ERR: error in degrees in the calculation of $\mathrm{S}_{\mathrm{HMAX}} . R=\left(\sigma_{2}-\sigma_{3}\right) /\left(\sigma_{1}-\sigma_{3}\right)$. E.F: number of faults explained by the stress tensor. $\mu$ : calculated friction coefficient.

comformably the Cretaceous and/or Paleogene formations at the basin margins, while this boundary seems to be conformable in the central part of the basin. During most of the Miocene, the basin was occupied by lakes and associated peripheral alluvial systems, forming a centripetal drainage system. Thus, a concentric facies distribution is observed (Calvo et al., 1989, 1996).

Three major tectono-sedimentary units separated by unconformities have been defined for the Miocene: Lower, Intermediate and Upper Miocene
Units, (Junco and Calvo, 1983). Analyzing the nature, extension and distribution of the alluvial fans and the fluvial distributary systems belonging to the Lower and Intermediate Units, a different tectonic activity is observed at the basin margins during their deposition (Alonso-Zarza et al., 1993).

The alluvial fans of the Lower Unit are related to the formation of the Altomira Range during the Lower Miocene and are represented by progressively finer and thinner graded bedding clastic sequences (Rodríguez-Aranda, 1995). An opposite situation is

Table 2

Strain ellipsoids and stress tensors calculated based on the slip model (Reches, 1983) and on the stress inversion method of Reches (1987) and Reches et al. (1992)

\begin{tabular}{|c|c|c|c|c|c|c|c|c|c|c|c|c|}
\hline \multirow[t]{2}{*}{ Stat. } & \multirow[t]{2}{*}{ N.F. } & \multicolumn{3}{|c|}{ Slip model } & \multicolumn{7}{|c|}{ Stress inversion } & \multirow[t]{2}{*}{ Age } \\
\hline & & Dey & S.D. & $K^{\prime}$ & $\sigma_{1}$ & $\sigma_{2}$ & $\sigma_{3}$ & ERR & $R^{\prime}$ & E.F. & $\mu$ & \\
\hline 62 & 17 & 152 & 5 & 1.45 & $73 / 355$ & $13 / 152$ & $05 / 243$ & 5 & 0.86 & 12 & 0.4 & Upper Miocene \\
\hline 63 & 20 & 166 & 11 & 2.48 & $01 / 166$ & $81 / 266$ & $08 / 076$ & 15 & 0.38 & 18 & 0.3 & Upper Miocene \\
\hline 64 & 4 & 118 & 7 & 0.62 & $61 / 315$ & $27 / 116$ & $07 / 210$ & 10 & 0.26 & 4 & 0.4 & Upper Miocene \\
\hline 65 & 16 & 130 & 10 & 0.63 & $76 / 142$ & $12 / 304$ & $07 / 035$ & 25 & 0.33 & 8 & 1.0 & Upper Miocene \\
\hline 66 & 20 & 132 & 12 & 0.61 & $80 / 143$ & $08 / 312$ & $09 / 044$ & 4 & 0.4 & 8 & 0.4 & Upper Miocene \\
\hline 67 & 22 & 151 & 4 & -11.5 & $08 / 327$ & $78 / 104$ & $07 / 236$ & 2 & 0.55 & 19 & 0.5 & Upper Miocene \\
\hline 68 & 7 & 144 & 4 & 3.37 & $56 / 331$ & $33 / 144$ & $03 / 236$ & 8 & 0.05 & 7 & 0.4 & Quaternary \\
\hline 69 & 8 & 145 & 10 & 0.445 & $04 / 128$ & $58 / 020$ & $31 / 220$ & 11 & 0.31 & 5 & 0.2 & Middle Miocene \\
\hline 70 & 13 & 160 & 3 & -4.637 & $01 / 161$ & $88 / 348$ & $00 / 251$ & 4 & 0.23 & 11 & 0.7 & Quaternary \\
\hline 71 & 9 & 129 & 9 & 0.095 & $81 / 320$ & $08 / 148$ & $01 / 058$ & 19 & 0.19 & 5 & 0.3 & Quaternary \\
\hline 72 & 11 & 140 & 7 & 3.72 & $78 / 015$ & $06 / 141$ & $09 / 232$ & 5 & 0.2 & 8 & 0.6 & Upper Miocene \\
\hline 73 & 17 & 145 & 11 & 0.11 & $78 / 046$ & $00 / 312$ & $11 / 221$ & 10 & 0.33 & 11 & 0.6 & Upper Miocene \\
\hline 74 & 24 & 161 & 10 & 0.402 & $20 / 163$ & $63 / 300$ & $16 / 066$ & 15 & 0.43 & 12 & 0.5 & Upper Miocene \\
\hline
\end{tabular}

For legend see Table 1. 

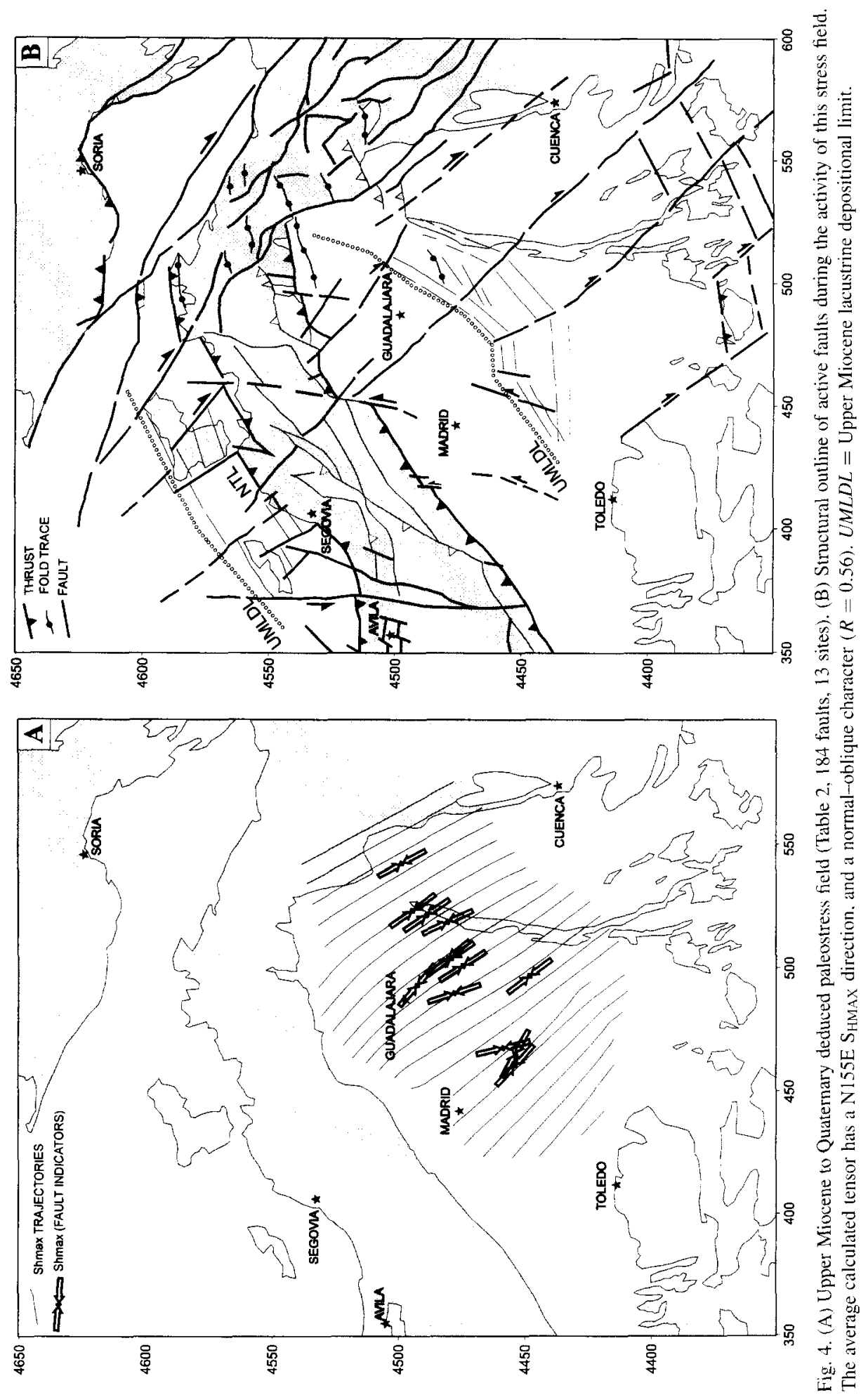


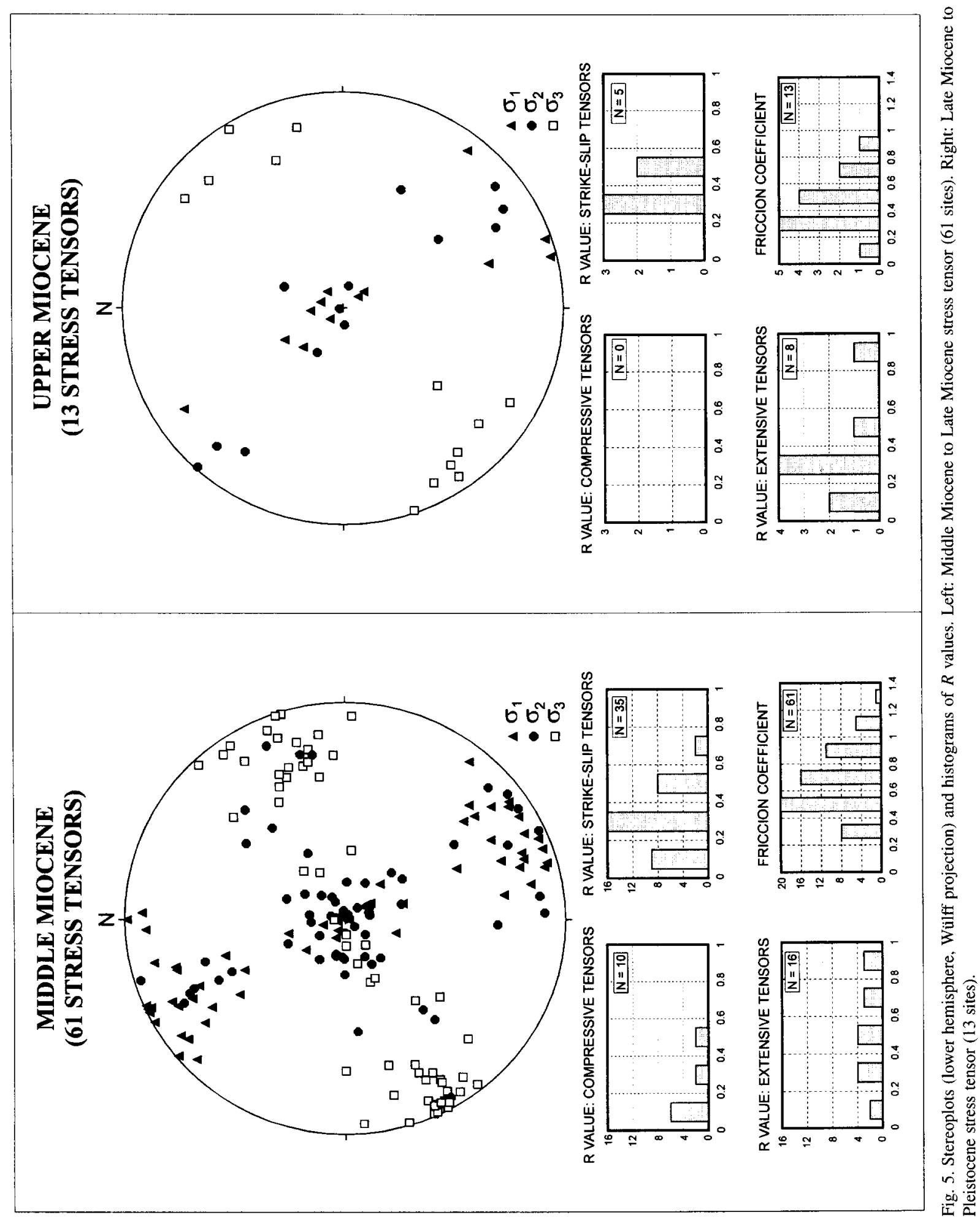


noted during the Middle Miocene, when Intermediate Unit lacustrine systems onlap the Altomira Range, suggesting that this border was inactive from a tectonic point of view. This unit appears clearly related to the major episode of formation of the Central System, since it represents a main southeastwards prograding alluvial fan system (Calvo et al., 1989). Coarsegrained facies are associated with the Central System south (SBF) and north (NBF) border faults (Figs. 2 and $3 \mathrm{~B}$ ), where they are locally thrust by Cretaceous and Paleozoic rocks. Two minor sequences can be found within this unit, which indicate tectonic activity of the basin borders: the lower one is related to the uplifted Central System, and the upper one to the Iberian Range (Alonso-Zarza et al., 1990). This indicates a less intense activity of the Central System compared to the Iberian Range from the Middle to Late Miocene. It could also suggest a gradual change in the stress regime, shifting to more transpressive types associated with the Iberian Range. It seems from the paleostress data that the stress regime changed significantly from the Middle Miocene to the Late Miocene. The two stages have similar SEtrending $\mathrm{S}_{\text {HMAX }}$ but the average stress regime is strikeslip to compressive for the first stage (transpressive), while it is extensive to strike-slip for the second one (transtensive). Nevertheless, the two groups of data have been obtained in different structural levels. In this way, we cannot assure that stress regime changed between the Middle and Late Miocene.

The Upper Miocene Unit consists mainly of fluvial terrigenous deposits and shallow lacustrine carbonates. Lacustrine deposits are restricted to the central and eastern parts of the Madrid Basin. Facies distribution is very different to that of the two previous units. It is important to point out that these materials outcrop far away from the south border fault, while they are very close to the north border fault (Figs. 2 and 4B). This could indicate a more important tectonic activity in the south border during the Late Miocene. A succession of uplifts and downfalls appear in the Tertiary sediments from the limit of the lacustrine facies (UMLDL, Fig. 4B) to the southeast, where the Quaternary drainage network settles down. The absence of deep seismic profiles keeps us from establishing this graben system deep structure, although we shall return to this point in view of the result of the seismic analysis.
During the Pliocene an erosion-dominated period began, which continues to the present. Materials in this period show a similar distribution to those of the Upper Unit, though there are few materials of this age. Nevertheless, they define a very characteristic erosional surface in this region. At present this surface is structured according to a large-wavelength flexure with an axis parallel to the Iberian Range. The Madrid Basin is located in the southwest flank of this flexure, and is tilted southwest. The Quaternary drainage network reflects clearly this situation, and forms an exorheic system draining towards the Atlantic.

Information related to fission track analysis on some blocks belonging of the inner part of the Central System indicates an important uplift episode between 7 and $10 \mathrm{Ma}$ (Sell et al., 1995). It could suggest a flexural response to the main tectonic event having occurred before in the Middle Miocene, as can be deduced from flexural analysis to determine the effective elastic thickness (EET) of the area (Van Wees et al., 1995).

The Neogene Valencia Trough opening was reflected clearly in the extensional stress field produced at the eastern part of the Iberian Peninsula (SimónGómez, 1986). This kind of deformation shifted to the west, and slowed down with time. Due to the Neogene facies distribution, this extensional episode does not appear in the Madrid Basin until, at least, the Late Miocene, and is more obvious in the Pliocene. Therefore, the post-Pliocene block rotation could be related to a generalized uplifting of all the eastern part of the Iberian Peninsula, as a late consequence of the Valencia Trough opening (Janssen et al., 1993).

\section{Present-day stress tensor characteristics}

Nine earthquakes recorded between 1979 and 1994, with magnitudes ranging between 3 and 4.1, and hypocentral depths between 15 and $1 \mathrm{~km}$ (Table 3 ) have been studied. Seven of them are located inside the Madrid Basin, one (No. 8) is located on the Central System South Border Fault (SBF) and the other (No. 9) towards the easternmost part of the Central System (Fig. 6B).

The method of Rivera and Cisternas (1990) has been applied to these earthquakes, with an average of 12 P-wave-first-arrival polarities per earthquake. 


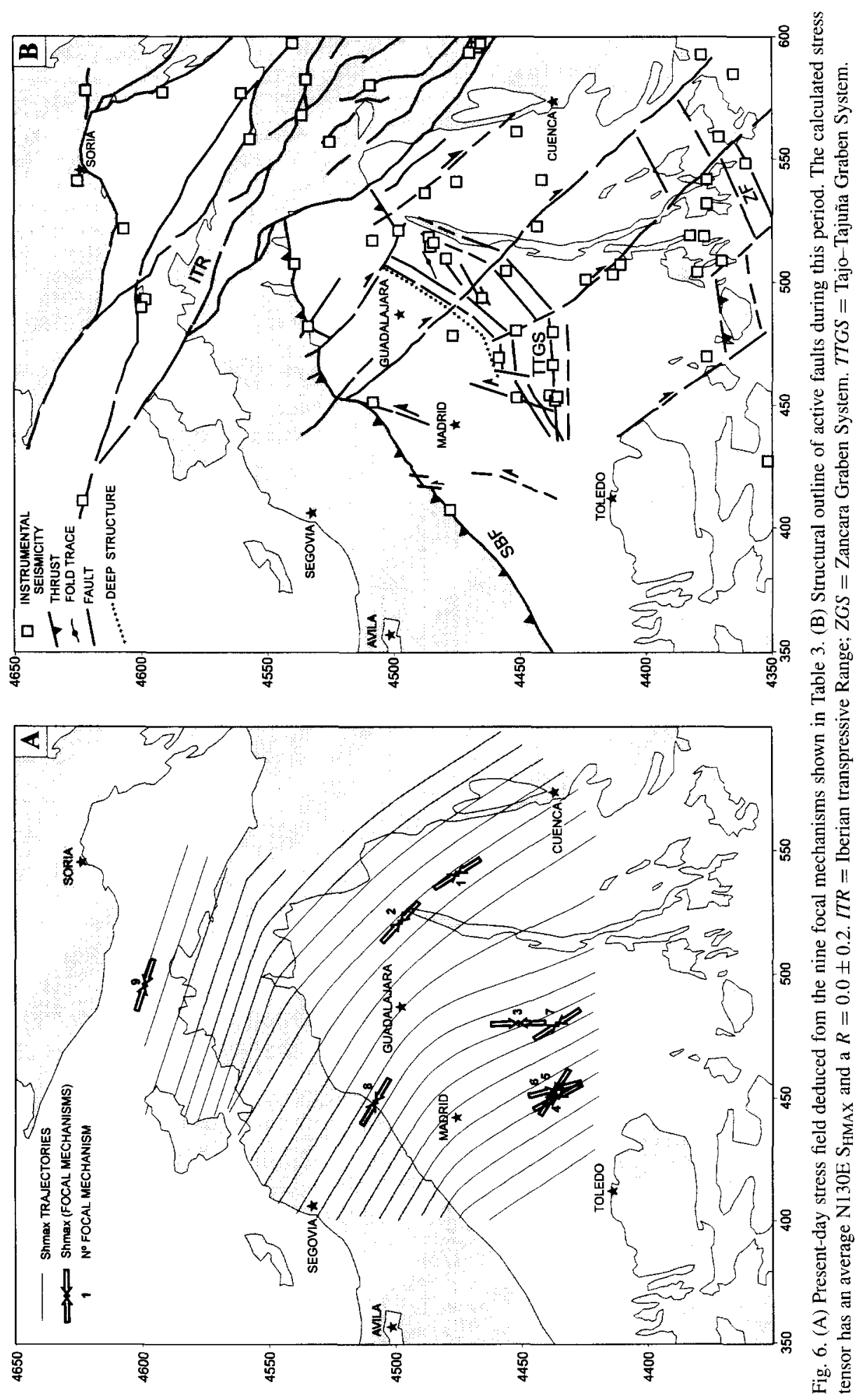


Table 3

Calculated focal mechanisms

\begin{tabular}{|c|c|c|c|c|c|c|c|c|c|c|c|c|c|}
\hline No. & Date & Time & Longitude $\left({ }^{\circ}\right)$ & Latitude $\left({ }^{\circ}\right)$ & Depth & RMS & $\mathrm{EH}$ & $\mathrm{EZ}$ & Mag. & Int. & Plane 1 & Plane 2 & Site \\
\hline 1 & 1979-06--30 & $01-44-35.9$ & $02-31.2 \mathrm{~W}$ & $40-25.8 \mathrm{~N}$ & 5 & 1.4 & 8 & 10 & 4.1 & & $43 / 111$ & $62 / 005$ & ALCOCER. GU \\
\hline 2 & $1982-02-23$ & $17-59-15.2$ & $02-45.0 \mathrm{~W}$ & $40-38.2 \mathrm{~N}$ & 15 & 1.3 & 3 & 7 & 4.1 & VI & $83 / 313$ & $11 / 183$ & DURON. GU \\
\hline 3 & $1987-10-19$ & $12-54-42.9$ & $03-13.8 \mathrm{~W}$ & $40-12.9 \mathrm{~N}$ & 5 & 0.2 & 1 & 1 & 3.2 & & $26 / 233$ & $75 / 132$ & V. SALVANES. M \\
\hline 4 & 1988-09-28 & $12-43-50.7$ & $03-32.1 \mathrm{~W}$ & $40-05.1 \mathrm{~N}$ & 1 & 0.3 & 2 & 4 & 3.0 & & $63 / 340$ & $36 / 300$ & ARANJUEZ. M \\
\hline 5 & $1988-10-04$ & $13-05-10.9$ & $03-33.6 \mathrm{~W}$ & $40-05.0 \mathrm{~N}$ & 2 & 0.3 & l & 3 & 3.1 & & $44 / 338$ & $35 / 358$ & ARANJUEZ. M \\
\hline 6 & $1988-10-11$ & $14-15-29.2$ & $03-34.6 \mathrm{~W}$ & $40-04.3 \mathrm{~N}$ & 1.5 & 0.4 & 2 & 3 & 3.1 & & $29 / 309$ & $58 / 122$ & ARANJUEZ. M \\
\hline 7 & $1988-10-24$ & $04-38-51.7$ & $03-14.0 \mathrm{~W}$ & $40-04.7 \mathrm{~N}$ & 9 & 0.4 & 2 & 2 & 3.4 & III & $39 / 114$ & $27 / 114$ & FUENTIDUEÑA. M \\
\hline 8 & $1990-07-07$ & $23-30-17.7$ & $03-34.5 \mathrm{~W}$ & $40-42.5 \mathrm{~N}$ & 2 & 0.8 & 2 & 2 & 3.3 & II-IV & $57 / 245$ & $45 / 234$ & S. A.GUADALIX. M \\
\hline 9 & 1994-04-06 & $03-33-00.0$ & $03-33.0 \mathrm{~W}$ & $41-33.0 \mathrm{~N}$ & 4 & 0.5 & 1 & 1 & 3.4 & $\mathrm{~V}$ & $26 / 304$ & $13 / 314$ & BURGO OSMA SO \\
\hline
\end{tabular}

Numbers refer to those of Fig. 5. Depth, horizontal (EH) and vertical errors (EZ) in km.

Regional strike-slip stress tensor has been obtained $(R=0.0 \pm 0.2)$. Main stress axes are $\sigma_{1}=17 / 320$, $\sigma_{2}=68 / 015$ and $\sigma_{3}=03 / 225$, with quite good quality parameters (Fig. 7A). Nevertheless, individually obtained focal mechanisms (Fig. 7B) correspond to seven reverse faults with a small strike-slip component and to two strike-slip-normal faults (No. 3 and 8 ). Because of the low number of analyzed earthquakes, a division of the population would not be appropriate. The calculated stress tensor presents an $R$ value of 0 because of the presence of reverse and normal faults with same trends (the same as microstructural data).

This situation is similar to the fault pattern observed in Upper Miocene and Quaternary materials. Thus, one of the characteristics of these stress fields could be a simultaneous reverse and normal fault activity. Absence of reverse faults at the surface could be an effect of different depths between analyzed faults and earthquake hypocentres.

In order to draw the associated $S_{\text {HMAx }}$ trajectories map, a projection of $\mathrm{P}$ axes (reverse faults) or $B$ axes (normal faults) on the horizontal plane has been used. $S_{\text {HMAX }}$ orientation and $\mathrm{P}$ axes do not necessarily coincide, but in low lateral-slip component focal mechanisms both orientations seem to be very similar (Fig. 6A).

\section{Seismicity distribution}

The instrumental earthquake epicentre distribution from 1979 to 1994 and magnitudes between 3 and 4.1 (Spanish Geographical Institute catalogue) in the studied zone, show the following (Fig. 6B). (a) The Central System southern border fault (SBF) has four epicentres on its trace in the last ten years, so that it could be considered slightly active. The SBF seems to be segmented by several NNE-SSW and NW-SE faults. Attending to the focal mechanism type, obtained on this fault (No. 8), the possibility of a higher seismic activity on these accompanying structures than in the southern border fault (SBF) can not be rejected. In any case, SBF is a seismic boundary that separates two zones: the Central System and the Duero Basin to the north, where the seismic activity is lower, and an area from the SBF to the south, where a great epicentre concentration appears between the UMLDL and the Záncara Graben System (ZGS). This latter zone consists of NE-SW- and E-W-trending graben systems (Fig. 6B).

(b) The Tajo-Tajuña Graben System (Fig. 6B, TTGS) is also segmented by N140E-trending faults, that are seismogenic towards the southeast. A normal fault system can be observed on the surface, that indicates a clear NW-SE extension. Although there is an extensional focal mechanism (No. 3) in this area, deep faults seem to be mainly reverse, indicating a NW-SE-shortening that agrees with fault-slip data. This situation could be explained by the presence of a crustal flexure compatible with the deduced shortening which produces normal faults parallel to the flexure axis at the surface. Nevertheless, this assumption can not be confirmed because of the absence of published deep seismic profiles.

(c) The Záncara River Fault (Fig. 6B, ZF), southwards of Altomira Range, shows similar characteristics to the previously described graben system, with 


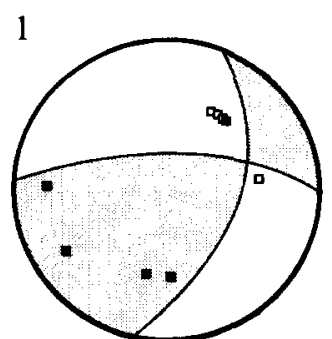

4

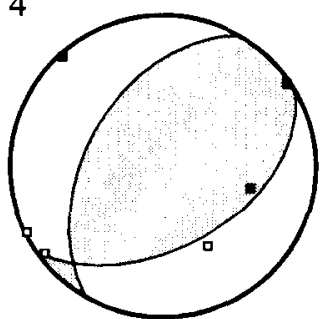

7

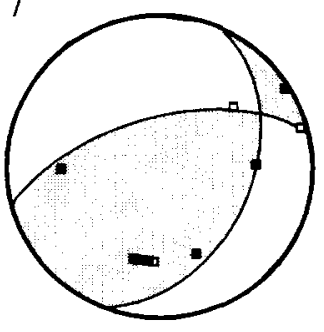

B

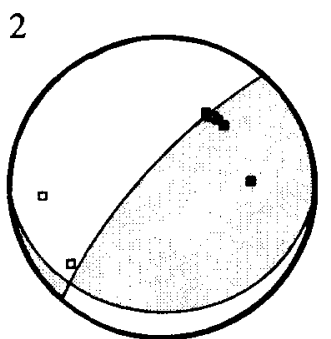

5

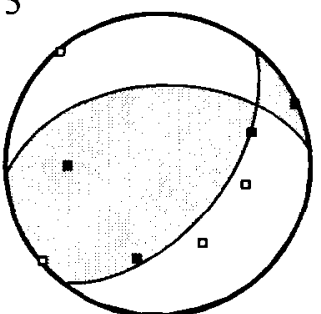

8

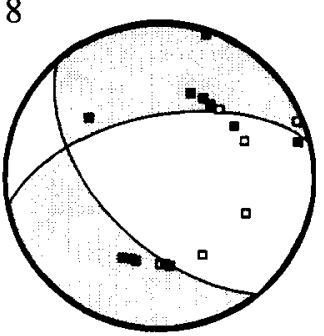

3

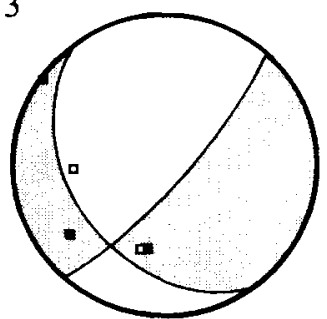

6

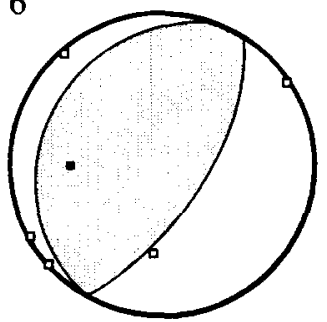

9

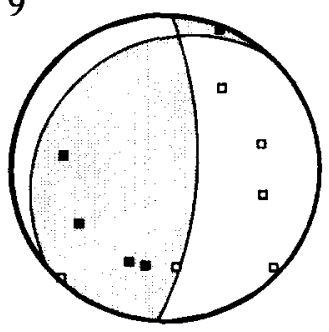

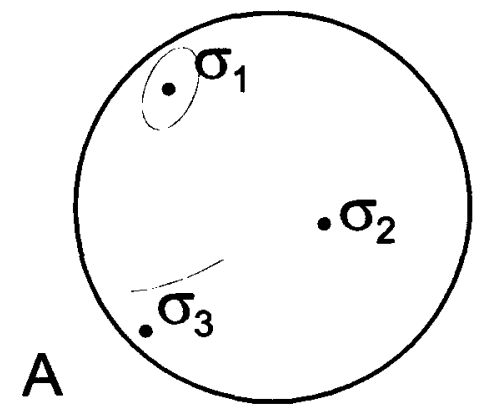

Shape factor: $\mathrm{R}=0.0+/-0.2$

Orientation: $\mathrm{phi}=201.7$

the $=23.0$

$\mathrm{psi}=25.8$

Quality: $\quad$ Likelihood $=0.893$

Score $=0.817$

Fig. 7. (A) Global solution. (B) Nine individual focal mechanisms obtained by the method of Rivera and Cisternas (1990) (see also Table 3) for the central part of Iberia.

a higher prevalence of strike-slip faults. The Toledo Mountains border seems to be inactive.

(d) The Iberian Range shows a moderate earthquake concentration. Specifically, two major earthquakes of the studied population (numbers 1 and 2) are located at the border between the Madrid Basin and this chain. Number 2 is generated on a NE-SW- trending structure, parallel to the Central System that may be interpreted as a NW-dipping active thrust. The rest of the earthquakes, located towards an inner part of this chain, are upon NW-SE mean trend faults. 


\section{Discussion and conclusions}

According to the results, present-day and neotectonic stress tensor characteristics, as well as the neotectonic period for the Madrid Basin and the Central System can be determined.

(a) The present stress tensor deduced from focal mechanisms has a N140E largest horizontal shortening trend, compatible with the one established by Müller et al. (1992) for Western Europe. This stress tensor activates mainly strike-slip and NESW-trending reverse faults.

(b) Major seismicity is concentrated on the Central System south border fault (SBF) and in the Tajo-Tajuña Graben System (TTGS). Both structures trend NE-SW, normal to the main horizontal shortening direction deduced for the active stress tensor. Nevertheless, numerous faults indicating NW-SE extension have been observed on the surface.

(c) Both Upper Cretaceous to Paleogene materials on the Madrid Basin margins and Upper Miocene and Quaternary materials of the central part of the basin record the neotectonic stress tensor. $S_{\text {HMAX }}$ trend is N155E, and all types of faults are active, although the most frequent correspond to strike-slip ones.

(d) Thus, the neotectonic period could be defined by the similarity between the present and neotectonic stress tensors with time. This similarity could be established as a function of stress tensor shapes $(R)$. $\mathrm{S}_{\text {HMAX }}$ trends, and the deformation intensity.

According to the stress tensor regime, it seems from the paleostress data that the stress regime changed from the Middle Miocene (transpressive) to the Late Miocene (transtensive). Although, one must consider that there are important differences in depth between the three considered data sources. Depths of earthquake hypocentres are larger than the fault-slip sites located on the basin surface, and perhaps equivalent (the most surficial ones) to some fault-slip data obtained at the basin borders. Thus, it is risky to establish evolutive rules of the stress tensor type with the three data sources. In any case, all described fault sets and the nine established focal mechanisms are compatible with a NW-SE largest horizontal shortening $\left(\mathrm{S}_{\text {HMAX }}\right)$.

On the whole, at the Madrid Basin and the Central System southern border fault, the $S_{\text {HMAX }}$ orientation shows a $\mathrm{S}_{\mathrm{HMAX}}$ trend difference of 10 degrees be- tween two average stress tensors calculated for both of the established paleostress fields (Middle to Upper Miocene and Upper Miocene to Quaternary) that does not seem to be large enough to separate two different stages, although change in basin fill characteristics is also recognized at this time, suggesting the activity of different geodynamic processes.

A $S_{\text {HMAX }}$ counterclockwise rotation can be observed between the Middle Miocene fault-slip data and the present-day stress tensors $\mathrm{S}_{\text {HMAX }}$ trajectories in the Central System and in the Duero Basin. Nevertheless, the latter have been defined only by two focal mechanisms and $P$ axes (not $S_{\text {HMAX orienta- }}$ tions), so their reliability depends on more complete studies. In this case, the neotectonic period in these areas began at least in the Late Miocene.

Deformation distribution and intensity suggest that active structures migrated from north to south with time: all of the described structures appear as clearly active during the Middle Miocene. The Late Miocene lacustrine facies distribution (UMLDL) makes it evident that there was higher tectonic activity at the south border fault (SBF) than at the north border fault (NBF). Pliocene tilting is more evident in the Madrid Basin than in the Duero Basin. Finally, the present earthquake distribution shows that the seismicity decreases from the Central System southern border fault to the north, and concentrates on the central part of the basin, on the Tajo and Tajuña River Graben System. From this point of view, the neotectonic period related to the Central System southern border fault (SBF) began in the Middle Miocene, while on the graben system of the central part of the Madrid Basin the neotectonic period could have started during the Pliocene.

\section{Acknowledgements}

The authors thank Dr. Rivera, Dr. Cisternas and Dr. Reches for allowing us to use their programs, and Dr. Lee for providing us with a version of his program LISSAGE.

The authors appreciate Dr. Delvaux and an anonymous referee's critical reading and improvement of the manuscript.

This work has been funded by the Spanish DGICYT grants: PB94-0242 and the Spanish Consejo de Seguridad Nuclear (CSN). 


\section{References}

Alonso, J.L., Pulgar, J.A. and García-Ramos, J.C. and Barba, P., 1996. Tertiary basins and Alpine tectonics in the Cantabrian Mountains (NW Spain). In: P. Friend and C. Dabrios (Editors), Tertiary Basins of Spain. Cambridge University Press, Cambridge, pp. 214-227.

Alonso-Zarza, A.M., Calvo, J.P., García del Cura, M.A. and Hoyos, M.A., 1990. Los sistemas aluviales Miocenos del borde noreste de la cuenca de Madrid: sector CifuentesLas Inviernas (Guadalajara). Rev. Soc. Geol. Esp., 3(1-2): $213-230$.

Alonso-Zarza, A.M., Calvo, J.P. and García del Cura, M.A., 1993. Paleomorphological controls on the distribution and sedimentary styles of alluvial systems, Neogene of the NE of the Madrid Basin (central Spain). In: M. Mazo and C. Puigdefabregas (Editors), Alluvial Sedimentation. Spec. Publ. Int. Assoc. Sedimentol., 17: 227-292.

Ancoechea, E., 1982. Evolución espacial y temporal del volcanismo reciente de España Central. Tesis Doctoral, Univ. Complutense, Madrid.

Angelier, J., 1990. Inversion of field data in fault tectonics to obtain the regional stress, III. A new rapid direct inversion method by analytical means. Geophys. J. Int., 103: 363-376.

Babín, R., Bergamín, J.F., Fernández, C., González, J.M., Hernández, J.L., Tejero, R. and De Vicente, G., 1993. Modélisation gravimétrique de la structure alpine du système central espagnol (secteur NE). Bull. Soc. Géol. Fr., 164(3): 385-393.

Blenkisop, T.G., 1982. Neotectonics. In: P.L. Hancock and G.D.. Williams (Editors), J. Geol. Soc. London.

Bott, M.H.P., 1959. The mechanism of oblique slip faulting. Geol. Mag., 96: 109-117.

Calvo, J.P., Alonso, A.M., García del Cura, M.A., Sanz, E., Hoyos, M., Ordoñez, S. and Pozo, M., 1989. Sistemas lacustres miocenos de la Cuenca de Madrid. Guia de Campo. V Reunión Grupo Español del Terciario, 16, CP-219.

Calvo, J.P., Alonso, A.M., García del Cura. M.A., Sanz, E., Ordoñez. S., Rodríguez-Aranda, J.P. and Sanz, M.E., 1996. Sedimentary evolution of lake systems through the Miocene of the Madrid Basin: paleoclimatic and paleohydrological constraints. In: P. Friend and C. Dabrio (Editors), Tertiary Basins of Spain. Cambridge University Press, Cambridge, pp. 272-277.

Capote, R., De Vicente. G. and González-Casado, J.M., 1990. Evolución de las deformaciones alpinas en el Sistema Central Español. Geogaceta, 7: 20-22.

Capote, R., De Vicente, G. and González-Casado, J.M., 1991. An application of the slip model of brittle deformation to focal mechanism in three different plate tectonics situations. Tectonophysics. 191: 399-409.

Delouis, B., Haessler, H., Cisternas, A. and Rivera. L., 1993. Stress tensor determination in France and neighbouringh regions. Tectonophysics, 221: 413-437.

De Vicente, G., 1988. Análisis Poblacional de Fallas. El sector de enlace Sistema Central-Cordillera Ibérica. Tesis Doctoral. Univ. Complutense, Madrid, 317 pp.

De Vicente, G. and González-Casado, J.M. (Editors), 1991. Las deformaciones alpinas en el Sistema Central Español. Mem.
III Reunión de la Comisión de Tectónica (Soc. Geol. España), Vol. I.

De Vicente, G., González-Casado, J.M., Muñoz-Martín, A., Giner, J.L. and Rodríguez Pascua, M.A., 1994. Evolución alpina del centro peninsular. Cuad. Lab. Xeol. Laxe, 19: 175190.

Dewey, J.F., Helman, M., Turco, E, Hutton, D.H.W and Knott, S.D., 1989. Kinematics of the western Mediterranean. In: M.P. Corward, D. Dietrich and R.G. Park (Editors), Alpine Tectonics. Geol. Soc. London, Spec. Publ., 45: 265-283.

Díaz-Molina, M. and Tortosa, A., 1996. Fluvial fans of the Loranca Basin, Late Oligocene--Early Miocene, central Spain. In: P. Friend and C. Dabrio (Editors), Tertiary Basins of Spain. Cambridge University Press, Cambridge, pp. 292-299.

Díaz-Molina, M., Arribas, A. and Bustillo, M., 1989. The Tórtola and Villalba de la Sierra fluvial fans: Late Oligocene-Early Miocene, Loranca Basin, central Spain. 4th Int. Conf. Fluvial Sedimentology, Barcelona-Sitges, Field trip 7.

Etchecopar, A., 1984. Etude des états de contraintes en tectonique cassante et simulations de déformations plastiques (approche matématique). Thése d'Etat, USTL, Montpellier.

García-Cuevas, C., González-Casado, J.M., Muñoz-Martín, A. and De Vicente, G., 1995. Determinación de los tensores de deformación y esfuerzo mediante el estudio comparado de poblaciones de fallas y del maclado mecánico de la calcita. Geogaceta, 18: 3-6.

Janssen, L.N., Torné, M., Cloetingh, S. and Banda, E., 1993. Pliocene uplift of the eastern Iberian margin: inferences from quantitative modelling of the Valencia Trough. Earth Planet. Sci. Lett., 119: 585-597.

Junco, F. and Calvo, J.P., 1983. La Cuenca de Madrid. Libro Jubilar J.M. Ríos (IGME), II: 534-543.

Lee, J-C. and Angelier, J., 1994. Paleostres trajectory maps based on the results of local determinations: the 'lissage' program. Comput. Geosci., 20(2): 161-191.

Megías, A.G., Ordoñez, S. and Calvo, J.P., 1983. Nuevas aportaciones al conocimiento geológico de la Cuenca de Madrid. Rev. Mat. Proc. Geol., 1: 163-191.

Mörner, N., 1990. Neotectonics and structural geology; general introduction. Bull. Int. Quat. Assoc. Neotect. Comm., 13.

Müller, B., Zoback, M.L., Fuchs, K., Mastin, L., Gregersen, S., Pavoni, N., Stephansson, O. and Ljunggren, Ch., 1992. Regional patterns of tectonic stress in Europe. J. Geophys. Res., 97(B8): 11783-11803.

Muñoz-Martín, A., De Vicente, G. and González-Casado, J.M., 1994. Análisis tensorial de la deformación superpuesta en el límite oriental de la Cuenca de Madrid. Cuad. Lab. Xeol. Laxe, 19: 203-214.

Pérez Agudo, M.E., 1995. Interpretación de ondas $\mathrm{P}$ y $\mathrm{S}$ en la Meseta Ibérica. Tesis de Licenciatura, Fac. CC Físicas, Univ. Complutense, Madrid, $88 \mathrm{pp}$.

Perucha, M.A., Muñoz-Martín, A., Tejero, R. and Bergamín, J.F., 1995. Estudio de una transversal entre la Cuenca de Madrid y la Cordillera Ibérica a partir de datos estructurales, sísmicos y gravimétricos. Geogaceta, 18: 15-18.

Querol, R., 1989. Geología del subsuelo de la Cuenca del Tajo. ITGE-ETSIM, Madrid. 
Reches, Z., 1983. Faulting of rocks in three-dimensional strain fields, II. Theoretical analysis. Tectonophysics, 95: 133-156.

Reches, Z., 1987. Determination of the tectonic stress tensor from slip along faults that obey the Coulomb yield condition. Tectonics, 7: 849-861

Reches, Z., Baer, G. and Hatzor, Y., 1992. Contraints on the strength of the upper crust from Stress Invesion of fault slip data. J. Geophys. Res., 97(B9): 12.481- 12.493

Rivera, L. and Cisternas, A., 1990. Stress tensor and fault plane solutions for a population of earthquakes. Bull. Seimol. Soc. Am., 80(3): 600-614.

Rodríguez-Aranda, J.P., 1995. Sedimentología de los sistemas de llanura lutítica-lago salino del Mioceno en la zona oriental de la Cuenca de Madrid (Tarancón-Auñón). Tesis Doctoral, Univ. Complutense, Madrid, 474 pp.

Sell, I, Poupeau, G., Casquet, C., Galindo, C. and GonzálezCasado, J.M., 1995. Exhumación alpina del bloque morfotectónico Abantos-Peñalara (Sierra del Guadarrama, SCE): potencialidad de la termocronometría por trazas de fisión en apatitos. Geogaceta, 18: 23-26.

Simón-Gómez, J.L., 1986. Analysis of a gradual change in stress regime (example of the eastern Iberian Chain, Spain).
Tectonophysics, 124: 37-53.

Suriñach, E. and Vegas, R., 1988. Lateral inhomogeneities of the Herynian crust in central Spain. Phys. Earth Planet. Inter., 51: 226-234.

Van de Beek, P.A. and Cloetingh, S., 1992. Lithospheric flexure and the tectonic evolution of the Betic Cordilleras (SE Spain). Tectonophysics, 203: 325-344.

Van Wees, J.D., Cloetingh, S. and De Vicente, G., 1995. The role of pre-existing weak zones in basin evolution: constraints from $2 \mathrm{D}$ finite element and 3-D flexure modelling. In: P.G. Buchanan and D.A. Nieuwland (Editors), Modern Developments in Structural Interpretation, Validation and Modelling. Geol. Soc. London, Spec. Publ., 99: 297-320.

Vegas, R,, Vázquez, J.T., Suriñach, E. and Marcos, A., 1990. Model of distributed deformation, block rotation and crustal thickening for the formation of the Spanish Central System. Tectonophysics, 184: 367-378.

Wallace, R.E., 1986. Active Tectonics. National Academic Press, Whasington, $266 \mathrm{pp}$.

Zoback, M.L., 1992. First- and second-order patterns of stress in the litosphere: The World Stress Map Project. J. Geophys. Res., 97: 11703-11728. 